\title{
THE DYNAMISM OF EXCHANGE RATE SHOCKS: EVIDENCE FROM NIGERIA
}

\section{Umar Faruq Quadri, Omokhagbo Mike Imafidor}

(1) Nigerian Institute of Social and Economic Research, Oyo Road, Ojoo, Ibadan, Nigeria, (2) Adams and Moore, Abia House, Abuja, Nigeria

Umar Faruq Quadri
Nigerian Institute of Social and Economic Research, Oyo Road, Ojoo, Ibadan, Nigeria
qufaruq@gmail.com

Article info
Paper category: Preliminary paper
Received: 6.4 .2018
Accepted: 17.1 .2019$.
JEl classification: Foo, F49
DOI: $10.32728 /$ ric.2018.44/4

Keywords Long-run equilibrium; Speed of Adjustment; Macroeconomic Fundamentals 


\begin{abstract}
Purpose. The main objective of this study is to investigate the dynamics of exchange rate shocks in Nigeria.

Methodology. The researcher used Error Correction Model (ECM) with annual time series data covering the period of 36 years; 1981 through 2016 as the estimation technique. The estimated co-integration test shows that the macroeconomic variables in the system do share a long run relationship with the exchange rates in the period under investigation. Accordingly, each variable in the system tends to adjust proportionally to bring in the system back to its long run equilibrium.

Findings and Implications. The estimation result shows that increase in productive output (gross domestic product) leads to depreciation of the exchange rate in the short run but with insignificant effect in the long run. This, hence, implies that the dwindling trend in domestic production has remained one of the major causal factors of the persistent fluctuation in exchange rate in Nigeria. The persistent rise in price level is equally found to lead to appreciation of the exchange rate simply because of over reliance on cheap and more sophisticated foreign goods and materials, in the short run but with insignificant effect in the long run. The domestic interest rate, as reveal by the estimation results, is found to be significantly impacted on the fluctuation of exchange rate in Nigeria.
\end{abstract}

Limitations. The main limitation of this study is in the area of data availability and model specification. The VAR model as popularized by Sims, (1980) is such that all the variables in the framework are assumed to be endogenous with the exception of exogenous variable. This problem may raise the tendency of for multicollinearity and the statistical insignificance of the regressors co-existing with high overall statistical significance of the regression model (Gujarati, 2005; Brooks, 2008).

Originality. To the best of my knowledge, at the time of conducting this research, many of the studies in Nigeria have employed other methods other than Vector Error Correction Model (VECM). And, we affirm that this work is original and not being considered elsewhere for publishing. Therefore, this study will contribute to existing literature on the dynamics of exchange rate shocks in Nigeria. 


\section{INTRODUCTION}

In the first year of the Millennium, according to Krugma, Obstfeld and Melitz (2013), Americans flocked to the Paris to enjoy French cuisine while shopping for designer clothing and other specialities. When measured in terms of dollars, prices in France were so much lower than they had been in a few years before that a shopper's saving could offset the cost of an airplane ticket from New York or Chicago. Five years later, however, the prices of French goods looked high to Americans. What are the economic implications of this widely swing of dollar prices of French goods?

The Nigerian national currency (naira) has depreciated by over 7000 per cent relative to the U.S. dollar since the introduction of Structural Adjustment Programme in Nigeria in 1986, falling from 2.0206/dollar in 1986 to over 160.7228/dollar by the fourth quarter of 2014 (Central Bank of Nigeria; 2013). Surprisingly, between the first quarter of 2013 and the fourth quarter of 2014, alone, the depreciation of naira against the dollar is about 3.20 per cent (Central Bank of Nigeria; 2013) and has since remained in this free fall range. This depreciation is noteworthy; not only because of its size, but also because of the nature of the Nigerian economy of being import-dependent and thus, the precarious situation that such a free-fall pushes the economy. Indeed, such a large and rapid fall of the naira is unprecedented in the post-Bretton Woods period. It seems the worst is yet to happen, the recent $(2015-2016)$ fluctuations of naira against the dollar in the parallel market in Nigeria is a food for thought for all! The most recent Central Bank of Nigeria's policy of abrogating official exchange rate is a pointer in another direction. Such prolong dramatic fluctuations of one currency against another presents a puzzle for economists and policymakers alike. Traditional exchange rates theories seem finding it difficult if not impossible, to explain both the immediate and remote impacts of such meteoric shocks on the macroeconomic variables.

Exchange rates can fluctuate meteoric over time. These fluctuations, and even just moderate exchange rate movements, can have significant impacts on output and prices in an economy. But unfortunately, notwithstanding the volume of substantial evidence in the academic literature and forecasting models, fundamental factors responsible for evolution of exchange rate fluctuations and how it will affect output growth and domestic inflation, at different points in time have had only limited success. This has posed challenges for monetary authorities which are forced to set monetary policy without a clear understanding of how exchange rate movements will affect key macroeconomic fundamentals over the medium term.

From exchange rates policy perspective, it is pertinent to understand the implications of such policy on the economy as a whole because different policies are likely to have different implications on the economy and may require different policy approaches. For example, naira may be responding to an increase in Nigerians' demand for imports or a decrease in foreign exchange earnings due to persistent fall in oil prices in the recent times, which has led to depletion of foreign reserves and its inherent impacts on 
the economy as a whole. In the alternative, maybe, the depreciation of the naira is attributable to general strengthening of the U.S. dollar. These possible scenarios, if either of them is the reason behind the free fall of the naira, call for different and appropriate policy to offset the free-fall of naira. With this puzzle yet unresolved, we revisit the academic literature on exchange rate to ascertain fundamental factors responsible for exchange rate shock with efforts of drawing inferences from both short-run and longrun macroeconomic models that link exchange rate with the selected macroeconomic variables in order to explain the likely effects of exchange rate shocks in Nigeria.

This work adopts a fundamental change to the methodology currently mainly used to analyse and measure transmission of exchange rate shocks to the selected macroeconomic aggregates. In many literature, attempts have been made to conduct econometric studies of the impacts of exchange rate shocks on the movements in output in Nigeria, Egwaikhde (1994); Odusola and Akinlo (2001); Ekpo (2003), Oladipo (2007), Omishakin (2009), Oyinlola and Babatunde (2009), Adijah, El-hamza and Biola (2009) Adetiloye (2009). In their studies, they made use of a number of methods to evaluate the transmission of exchange rate shocks to selected aggregates. Disappointedly, many of these earlier studies were based on single equation regression and simultaneous equation modelling approaches. However, Ogunleye, Igue and Aremu (2012) adopted non-recursive VAR to evaluate impacts of exchange rate shocks on domestic prices in Nigeria. Unfortunately, many of these approaches seem to have been unable to capture the peculiar features of the Nigerian economy; the long-run phenomenon which exchange rate shock is associated, as well as the trends and dynamics in the data. To the best of my knowledge, at the time of conducting this research, most studies have employed other methods other than Error Correction Model (ECM). This paper, thus, seeks to re-evaluate the dynamism of exchange rate shocks with evidence from Nigeria by selected macroeconomic aggregates of changes in interest rate, change in domestic prices (inflation) and change real GDP.

Against this backdrop, this paper is intended to provoke and pave ways for further studies on the subject matters as it reveals the difficulty in resolving the empirical question on the macroeconomic fundamentals responsible for exchange rate shocks in Nigeria.

\section{REVIEW OF RELEVANT LITERATURE}

This section presents a review of literatures to put the study in context. The review covers both theoretical and empirical findings.

\subsection{Exchange Rate Shocks: Conceptual Issues}

Exchange rate is the rate at which one country's currency is exchanged for the currency of another country (Dornbusch, 2004). It can also be defined as the price of one country's currency relative to other countries' currency. While, Mankiw (1997) 
defines it as the price at which exchange between two countries take place. How to determine the exchange rate is issue that has taken the centre stage of monetary and international economics. Monetary policy authority in Nigeria is faced with the problems of having a stable and realistic exchange rate which is in consonance with other macroeconomic fundamentals. This is because exchange rate instability can have serious adverse consequences on prices, investments and international trade decisions. A realistic exchange rate is one that reflects the strength of foreign exchange inflow and outflow, the stock of reserves as well as ensuring equilibrium in the balance of payments that is consistent with the cost and price levels of trading partners (Ojo, 1998).

While exchange rate shocks implies the ability of a country's currency relative to another country's currency to fluctuate over time. Exchange rate shocks is a term used to describe a phenomenon that occurs when the value of one currency spikes relative to another in an extremely short period of time. Exchange rate shocks could depend on two basic policies, that is the fixed exchange rate policy and the flexible exchange rate policy. By fixed exchange rate policy (regime), we mean a situation, when the exchange rate is set and government is committed to buying and selling its currency at a fixed rate, while flexible exchange rate policy defines a situation when the exchange rate is set by market forces (demand and supply for a country's currency). Beyond directly influencing different economic channels, exchange rate shocks have policy implications which are not as easily understandable. This shock have found to have significant impact on inflation, interest rate, real gross domestic product and other fundamental macroeconomic aggregates.

The high volatility of foreign exchange rates surprises many people. Approximately forty-five years ago, economists generally believed that allowing exchange rates to be determined in the free market would not lead to large fluctuations in their values. Surprisingly, recent experience has proved them wrong. Findings have shown that exchange rates over the 1986-2016 in Nigeria for instance, after the introduction of flexible exchange regime, have been very volatile.

In addition, we have equally seen that exchange rate analysis produces exchange rate overshooting when the money supply increases. Exchange rate overshooting is an additional reason for the exchange rates shocks in Nigeria. Because earlier models of exchange rate behaviour focused on goods markets rather than asset markets, they did not emphasize changing expectations as a source of exchange rate movements, and so these earlier models could not predict substantial fluctuations in exchange rates. The failure of earlier models to explain shocks is one reason why they are no longer so popular.

The more modern approach emphasizes that the foreign exchange market is like any other asset market in which expectations of the future matter. The foreign exchange market, like other asset markets such as the stock market, displays substantial price volatility, and foreign exchange rates are notoriously hard to forecast. 


\subsection{Theories/Models of Exchange Rate Shocks}

In general, two models of exchange rate shocks would be discussed to form the main theoretical frameworks upon which this study hinges; they include the purchasing power parity model, and the more modern asset market theory of exchange rate.

The purchasing power parity is a simple theory of equilibrium exchange rate determination and is used mainly for cross-country composition of living standards and examining the productivity levels over time as well as determining the relative value of currencies (Vachris and Thomas, 1999 as cited by Omolara et al; 2012). This theory is based on the proposition that exchange rates would adjust to equalize the relative purchasing power of currencies. Thus, it is expected that in perfectly competitive markets, identical products would trade at equivalent prices when valued in the same currency.

The PPP theory is based on the notion that the exchange rate is dependent on the actual buying power over a basket of goods, and so changes in the nominal exchange rate should reflect changes in the prices of goods (Taylor and Taylor, 2002, as cited in Omalar et al; 2012). Thus, the PPP theory is rooted on the concept of the "law-of-one-price" which assumes that nominal exchange rates should change to compensate for price differentials across countries. In its simplest form, the law-ofone-price can be expressed as:

$P_{t}=P_{t x} S_{t}$

Where:

$\mathrm{P}_{\mathrm{t}}$ domestic prices for a good or basket of goods

$\mathrm{P}_{\mathrm{t}}^{*}$ : foreign prices for a good or basket of goods and,

$\mathrm{S}_{\mathrm{t}}$ : spot/ market determined exchange rate; units of domestic currency in terms of a unit of foreign currency.

If PPP holds, then equation 2.1 can be re-arranged to derive the form of absolute PPP.

The left hand side of equation 2.1 can also be referred to as the real exchange rate or the exchange rate that has been adjusted for relative price levels. It differs from absolute PPP approach as it takes into cognizance changes in prices and exchange rate. This implies that the expected changes in the exchange rates would be equivalent to the change in the ratio of the two countries' price level, given that there are no changes in fundamentals relationships. Thus the relative PPP model which establishes a relationship between the price indices of both domestic and foreign countries is given as follows:

$\mathrm{St}^{2}-\mathrm{St}^{1}=\pi_{\mathrm{t}}-\pi_{\mathrm{t}}^{*}$

Or $\% \Delta \mathrm{S}_{\mathrm{t}}=\% \Delta \mathrm{P}_{\mathrm{t}}-\% \Delta \mathrm{P}_{\mathrm{t}}^{*}$

Where;

$\pi_{\mathrm{t}}$ : domestic inflation, and the depreciation

$\pi_{\mathrm{t}}^{*}$ : foreign inflation

$\mathrm{S}_{\mathrm{t}}$ : rate of depreciation of domestic currency 
In equation 2.2, it can be seen that the percentage change in exchange rate over a given range of time will be equal to the differences in inflation of domestic economy and that of the foreign economy. Put in a slight different form, equation 2.3 reveals the differences in percentage changes in price levels in the domestic country and foreign country, also known as the changes in the relative inflation, as direct determinants in the relative changes in exchange rate between the two countries. It is thus, the calculation of the relative PPP that many economists and theorists normally anchor their empirical tests in order to establish the validity of PPP.

However, this theory has few shortcomings that makes it difficult to explain exchange rate shocks in the short run. The PPP conclusion that exchange rates are determined solely by changes in relative price levels rests on the assumption that all goods are identical in any two given countries and that transportation costs and trade barriers are very low. The assumption that goods are identical may not be too unreasonable in reality. PPP theory furthermore does not take into account that many goods and services (whose prices are included in a measure of a country's price level) are not traded across borders. Housing, land, and services such as restaurant meals, haircuts, and golf lessons are not traded goods. So even though the prices of these items might rise and lead to a higher price level relative to another country's, there would be little direct effect on the exchange rate.

We have discussed the PPP theory of the long-run behaviour of exchange rates. However, in order to understand why exchange rates exhibit such large changes (sometimes several percent) from day to day, the theory of how current exchange rates (spot exchange rates) are determined in the short run as explained by the asset market theory is reviewed.

Writing the currency exchange rate (the spot exchange rate) as $\mathrm{E}_{\mathrm{t}}$ and the expected exchange rate for the next period as $\mathrm{E}_{\mathrm{t}+1}{ }^{*}$, we can write the expected rate of appreciation of the naira as $\left(\mathrm{E}_{\mathrm{t}+1}{ }^{*}-\mathrm{E}_{\mathrm{t}}\right) / \mathrm{E}_{\mathrm{t}}$. Our reasoning indicates that the expected return on naira deposits $\mathrm{R}^{\mathrm{D}}$ in terms of foreign currency (dollars) can be written as the sum of the interest rate on dollar deposits plus the expected appreciation of the dollar:

$\mathrm{R}^{\mathrm{D}}$ in terms of dollars $=\mathrm{i}^{\mathrm{D}}+\frac{(\mathrm{Et}+1 *-E t)}{E t}$

Thus in terms of dollars, the relative expected return on naira deposits (that is, the difference between the expected return on naira deposits and dollar deposits) is calculated by subtracting $\mathbf{i}^{\mathrm{F}}$ from equation 2.4, to yield equation 2.5:

$\mathrm{R}^{\mathrm{D}}$ in terms of dollars $=\mathrm{i}^{\mathrm{D}}-\mathrm{i}^{\mathrm{F}}+\frac{(\mathrm{Et}+1 *-E t)}{E t}$

As the relative expected return on naira deposits increases, foreigners will want to hold more naira deposits and fewer foreign deposits (dollars). 


\subsection{Review of Empirical Literature}

\subsubsection{Trends in Exchange Rate Shocks in Nigeria}

The naira which has served as the Nigerian currency since 197, started very strongly against the dollar for a number of years. Naira was stronger than the US dollar in the earliest period of the Nigerian political independence in 1960. This was partly supported by the strong productive capacity of the economy. Although, the Nigerian economy has always been an exporter of primary commodities even in the pre-independence period, as automated to operate by the colonialists, the economy had been able to achieve a positive balance of payments. Thus, this largely accounts for the economy maintaining the projectile of producing primary products to the rest of the world many years into independence (Sharehu 2015).

Figure 1. : Trends of Exchange Rate in Nigeria

Official exchange rate (LCU per US\$, period average)

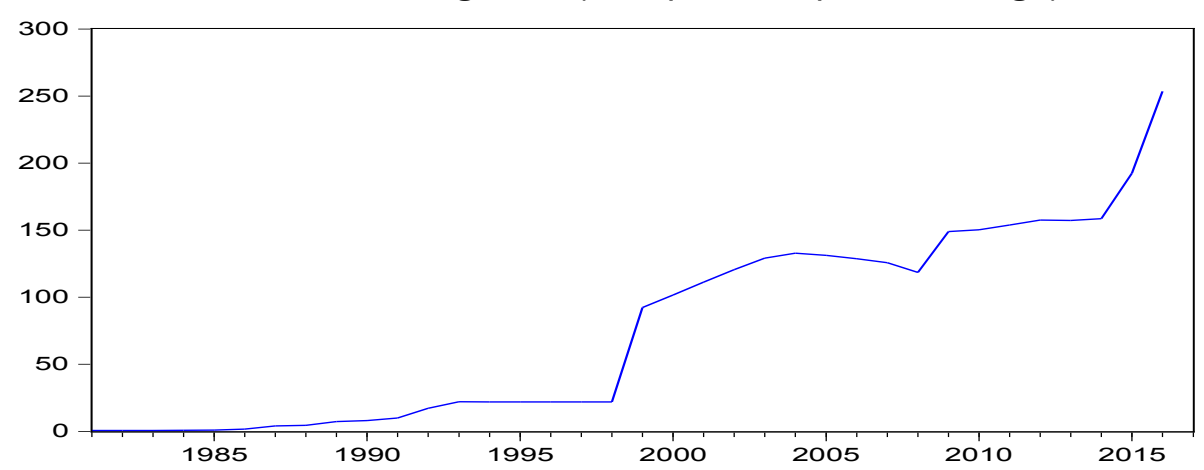

Source: CBN 2016.

Consequently, the naira maintained a robust Naira/Dollar exchange rate for some years. This is as depicted in the chart in Figure 1. It is noteworthy that over this period the country was exclusively practising a fixed exchange rate regime. It is also crucial to know that the economy reaped surplus from oil boom in the mid-7os. However, it is imperative to know the fixed exchange rate regime was never in tandem with prevailing economic realities.

International pressure on the government to deregulate the economy in order to devalue a perceived over-valued naira heightened after a series of budget deficits as a result of global financial crisis of the early 8os. The crisis which saw the government borrowings in order to sustain the fixed exchange rate of the Naira/dollar increased monumentally for a number of years. As the oil glut ended due to weak demand in addition to debt profile used to finance the deficits in the budgets, the government gave in to pressure and relaxed the exchange rate regime to a flexible 
one. The deregulation of the economy and the domestic currency devaluation came into effect precisely in 1986.

\subsubsection{Empirical Literature from Developed Economies}

A review of studies conducted in advanced countries includes Feyzioglu (1997) who examined the real exchange rate in Finland during the period between 1975 and 1995. He made use of Johansen Co-integration techniques and the result showed that positive terms of trade shocks, world real interest rates and productivity differential between Finland and its main trading partners contributed to the appreciation of the real exchange rate. He found out that the real exchange disequilibrium persisted for long periods and it would take about one and a half years to correct 5 o per cent of such disequilibrium.

In their work, Clostermann and Schnatz (2000), equally examined the real exchange rate on the euro-dollar relationship. They assessed the major determinant factors that drive changes in real exchange rate in the European zone between 1975 and 1998. They constructed a synthetic real euro-dollar exchange rate and used cointegration techniques and the error correction model for their study. Their findings revealed that the international real interest rate differential, relative prices in the goods sector, real oil prices and government spending accounted for significant changes in the real exchange rate. They equally estimated the medium-term equilibrium exchange rate of the euro to be 1.13 dollar/euro.

In a similar vein, Lorenzen and Thygenssen (2000) carried out a study on the euro-dollar link indicated that net foreign assets, demographics, research and development spending and the relative prices of the goods sector accounted for changes in the euro. They observed that the estimated euro-dollar exchange rate ranged from 1.17 dollar/euro to 1.24,dollar/euro.

In a related study, Chinn (2000) investigated the behaviour of the dollar/euro exchange rate using the monetary approach to the exchange rate. Variables analysed included money stocks, industrial production, interest and inflation rates, relative price of non-tradables and synthetic euro. He used co-integrating VAR analysis to found that the real values of the euro lied between 1.15 dollar/euro and 1.17 dollar/euro and that euro was undervalued by about 13.0 to 15 . o per cent in January 2000 , implying that it was below its equilibrium value.

\subsubsection{Empirical Literature from Developing Economies}

The impact of exchange rate regimes and selected macroeconomic fundamentals on dynamics of exchange rate shocks have been analysed in many empirical studies for developing countries. However, the findings of these studies differ and cannot be generalized. Impacts of exchange rate regimes; fixed or flexible; on exchange rate 
fluctuation is more ambiguous. Meanwhile, most of the empirical findings confirm that the depreciations of the nominal exchange rate are related to temporary increases in domestic prices.

According to Gosh et al (1997); there are evidence that the mean inflation rate is lower in economies with a fixed exchange rate than in those with a more flexible exchange rate. Accordingly, Aghevli et al. (1991) came up similar results, but however showed that many countries with fixed exchange rate regimes have experienced a high rate of inflation consequent upon inadequate fiscal policies.

Quirk (1994) observes that the differences between the various exchange rate regimes have been reduced, once the adjustments in the case of fixed exchange rate regimes are taken into account. Similarly, he demonstrated that the stability of the exchange rate has become a "by-product" of other political options. As revealed in the literature, many developing economies have been subjected, since the mid1980 s, to frequent shocks in the terms of trade and, thus, have adopted more flexible exchange regimes to avoid the deterioration of external competitiveness. However, according to Kamin (2003) in Mexico, the real depreciation of the peso had a strong inflationary impact. In general, it seems that not only changes in the nominal exchange rate, but also the level of the effective real exchange rate are correlated with the inflation rate.

In their work, Mahamadu and Philip (2003) explore the relationship between monetary growth, exchange rates and inflation in Ghana using the Error Correction Mechanism. The empirical result confirms the existence of a long-term equilibrium relationship between inflation, the money supply, the exchange rate and real income. According to the theory, the findings show that in the long term, inflation in Ghana is positively related to the money supply and the exchange rate, while it is negatively related to real income.

Dick and Ndung'u (1998) develop an error correction model with the objective of analyzing the behavior of prices in Kenya during 1974-1996. Using the Johansen procedure, they conducted a co-integration test in the currency and exchange markets. They found that in the long term, inflation emanates from movements in the exchange rate, foreign prices and terms of trade, while the money supply and the interest rate influence inflation in the short term. These findings indicate that the exchange rate is likely to be a nominal anchor more efficient than the money supply.

T.O. Akinbobola (2012) investigates the dynamics of money supply, inflation and exchange rate in Nigeria, adopting Vector Error Correction Model (VEGM). He argues that the main cause of price fluctuation in many developing economies is the exchange rate fluctuation. There are several reasons for this. In import dependent country like Nigeria, changes in exchange rate are directly reflected in the prices of the goods and services.

Odusola and Akinlo (2001) investigate the link between depreciation, inflation and naira production in Nigeria, adopting Vector Self-Regress (VAR) and its struc- 
tural variant. Their findings suggest that the adoption of a flexible exchange rate system does not necessarily lead to the expansion of production, particularly in the short term. Issues such as discipline, trust and credibility on the part of the government are essential.

According to Akpan and Atan (2012), using a Generalized Method of Moments (GMM) procedure, found a statistical significant relationship between exchange rate and economic growth in Nigeria in the short-run, but in the long-run, the two variables drifted apart.

Rodrik (2008) dramatically argues differently about the reason exchange rate shocks matter for economic growth and also about the empirical relationship. In large sample of developing countries over 1950-2004 period, he discovers that economic growth over the medium term is much higher in countries with more undervalued exchange rates, and that the effect is linear and similar for both under and overvaluation of exchange rate; implying that overvaluation hurts economic growth but undervaluation spurs it. This evidence is also corroborated by the evidence form Rajan and Subramanian (2007); Dollar and Kraay (2003); Razin and Collins (1997). McCarthy (2000) used the VAR model in estimating exchange rate impact on domestic prices at the aggregate level for several developed economies. He concluded that impact of exchange rate on domestic prices was minimal for most of the countries. Impacts of exchange rate shocks on domestic prices was found to be incomplete and higher in both magnitude and speed (Campa and Goldberg, 2005).

\section{RESEARCH METHODOLOGY}

This section discusses explicitly the methodology and estimation related issues in line with the objectives of this study. The source of data is stated and the theoretical framework is developed also.

\subsection{Source of Data and Estimation techniques}

The main focus of this research work is on the dynamism of exchange rate shocks in Nigeria. The paper thus, makes use of annual time series data covering the period of 36 years; 1981 through 2016 and were obtained mainly from the World Economic Index.

In order to isolate and analyse the impact of selected variables on exchange rate shocks, EGM models are relied upon such as ARDL bound testing, impulse response functions (IRFs) and Forecast Error Variance Decomposition (FEVD). These methods are utilized in order to ascertain the trends in the macroeconomic aggregates under study as stated in the introductory section of the paper. 


\subsection{Model Specification}

In the literature, series of factors have been adduced as the evident behind exchange rate evolution in Nigeria. Meanwhile, the focus of this study is in line with the monetary theory of exchange rate. The following econometric model based on the $4 \mathrm{x}$ 4. matrix regression equations were formulated:

$\ln Z_{\mathrm{t}}=\emptyset_{\mathrm{i}}+\Sigma \beta_{\mathrm{i}} \ln \mathrm{Z}_{\mathrm{t}-1}+\varepsilon_{\mathrm{t}}$

where;

$\ln Z_{t}=\left(\operatorname{lnEXR}, \operatorname{lnGDP}_{t}\right.$, INFR $_{\mathrm{t}}$ INTR $\left._{\mathrm{t}}\right)$; the vector of the of the log values of nominal exchange rate (EXR), nominal gross domestic product(GDP), Inflation rate (INFR) and interest rate (INTR).

$\emptyset_{\mathrm{i}}=$ intercepts of the autonomous variables.

$\beta_{\mathrm{i}}=$ matrix of the coefficients of all the variables in the model

$\mathrm{Z}_{\mathrm{t}-\mathrm{1}}=$ vector of the lagged variables.

$\varepsilon_{\mathrm{t}}=$ vector of the white noise error term.

Going by the model above, the functional relation between the variables can be implicitly shown as below:

$\ln E X R=F(\ln G D P, I N F R, I N T R)$

where;

lnEXR = ln of nominal exchange rate,

$\ln R G D P=$ ln of nominal gross domestic product,

INFR = Inflation rate and

INTR = Interest rate .

\section{ANALYSIS OF ESTIMATION RESULTS AND FINDINGS}

This paper explore the co-integration and Error Correction Mechanism (ECM) method. This is due to the fact that the selected variables of interest are found to relate to dynamics exchange rate, thus the need to treat the variables symmetrically and allow feedback among them. Second, EGM analysis is superior to the orthodox VAR for capturing the long-run dynamics of exchange rate. This technique enables us to verify the stationarity as well as the order of integration of the variables used in the model. The method also enables us to establish the longrun relationship between exchange rate, gross domestic product interest rate and inflation.

\subsection{Unit Root Test}

Empirical findings have shown that most economic time series are strongly trended and hence non-stationary (Iyoha M.A. 2004). The Unit Root Test is conducted to verify the stationarity or otherwise of the selected macroeconomic vari- 
ables. The result of the Augmented Dickey Fuller (ADF) and Phillips-Perron (PP) used in the study are shown in Table 1.

Table 1. : Unit Root test

\begin{tabular}{|c|c|c|c|c|c|c|c|c|}
\hline \multirow[b]{3}{*}{ Variable } & \multicolumn{6}{|c|}{ AUGMENTED DICKEY-FULLER } & \multicolumn{2}{|c|}{$\begin{array}{c}\text { Phillips-perron } \\
\text { Statistic }\end{array}$} \\
\hline & \multicolumn{2}{|c|}{ AIC } & \multicolumn{2}{|c|}{ SBC } & \multicolumn{2}{|c|}{ HQ } & \multirow[b]{2}{*}{ Level } & \multirow[b]{2}{*}{$\begin{array}{l}\text { First } \\
\text { Diff. }\end{array}$} \\
\hline & Level & $\begin{array}{l}\text { First } \\
\text { Diff.a }\end{array}$ & Level & $\begin{array}{l}\text { First } \\
\text { Diff. }\end{array}$ & Level & $\begin{array}{l}\text { First } \\
\text { Diff. }\end{array}$ & & \\
\hline $\operatorname{lnEXR}$ & -1.90574 & $-5.0265^{*}$ & -1.90574 & $-5.0265^{*}$ & -1.90574 & $-5.0265^{*}$ & $-2.034,21$ & $-5.0265^{*}$ \\
\hline $\operatorname{lnGDP}$ & 0.297192 & $-5.2820^{*}$ & 0.297192 & $-5.2820 *$ & 0.297192 & $-5.2820 *$ & 0.185485 & $-5.2690 *$ \\
\hline INFR & $-5.6964^{*}$ & $-7.1276^{*}$ & $-5.6964^{*}$ & $-7.1276^{*}$ & $-5.6964^{*}$ & $-7.12764^{*}$ & $-5.6964^{*}$ & $-27.112^{*}$ \\
\hline INTR & -2.804 .87 & -2.484 .67 & -2.4 .0276 & $-5.1321^{*}$ & -2.4 .0276 & -2.48467 & -2.3816 & $-6.5282^{*}$ \\
\hline
\end{tabular}

Note: ${ }^{*}{ }^{* *}$, and ${ }^{* * *}$ represents statistical significance at $1 \%, 5 \%$ and $10 \%$ respectively

Source: Authors' Results from E-views 9 for Windows.

Prior to the examination of the long-run relationship between exchange rate and the selected macroeconomic fundamentals, the times series properties of the variables are first investigated using $\mathrm{ADF}$ and $\mathrm{PP}$ tests. The $\mathrm{ADF}$ test was based on Akaike Information Criterion (AIC), Scwarz Information Criterion (SIC) and Hannan-Quinn Information Criterion (HQ). The three criteria chosen for the ADF and the PP revealed that exchange rate and gross domestic product are I(1) variables. While the interest rate is shown to be I(1) variable by the PP and the is supported by HQ criterion of the ADF. However, the inflation rate is found to be $\mathrm{I}(\mathrm{O})$ variable by both ADF and PP.

\subsection{Selection of Optimal Lag Length of the Model}

Table 2. : VAR Lag Length Selection Criteria-LHCPI

\begin{tabular}{|c|c|c|c|c|c|c|}
\hline Lag & $\log L$ & LR & FPE & AIC & $\mathrm{SC}$ & HQ \\
\hline 0 & -311.01 & $\mathrm{NA}$ & 7877.5 & 20.3232 & 20.5082 & 20.3835 \\
\hline 1 & -203.35 & $180.5^{82}$ & $21.5^{384} 6^{*}$ & $14 \cdot 41$ & $15.33_{5} 3^{*}$ & $14 \cdot 7115^{*}$ \\
\hline 2 & -191.81 & 16.3835 & 30.4107 & 14.6975 & 16.3628 & 15.24 .04 \\
\hline 3 & $-17^{8} \cdot 5^{8}$ & 15.3696 & 42.3027 & 14.8759 & 17.2813 & 15.66 \\
\hline 4 & -14.8 .62 & $27.05456^{*}$ & $23.7 \circ 5$ & 13.9757 & 17.1212 & 15.0011 \\
\hline 5 & -126.47 & 14.2916 & $30.04,18$ & $13.57882^{*}$ & 17.4645 & 14.8454 \\
\hline
\end{tabular}

* indicates lag order selected by the criterion

Source: Authors' Results from E-views 9 for Windows.

Thus, the optimum lag length of 1 is chosen based on FPE, SC and HQ criteria as shown in Table 2. And the residual of the VAR is tested for autocorrelation at this lag length, the residual is found to be free of serial correlation. Hence, the lag length 
of 1 is chosen as the optimum lag; this equally confirmed what is usually expected of annual data.

\subsection{Analysis of Long run Effects of Gross Domestic Product, Inflation and Interest Rate on Exchange rate}

To obtain the long run impact of the selected macroeconomic variables on the exchange rate, Error Correction Mechanism (ECM) which incorporates both the long run and short run effect simultaneously is estimated. The elegancy of this estimation technique is that once variables are non-stationary but co-integrated, the estimates from ECM are more efficient than either the Ordinary Least Square or orthodox VAR estimates. The EGM is also devoid of endogeneity problem and the inherent spurious inferences associated with OLS estimates.

The ECM is a gauge of the speed of adjustment of the short run relation to unexpected shocks. It is measured as the effects of residual from the long run model. This long run feedback effect is indicated by significant ECM terms while the short run causality is measured by the significant coefficient on the individual variables.

To establish the presence of a long-run equilibrium relationship among the non-stationary variables, the Johansen and Juselius (1990) co-integration test using the trace and max-eignvalue tests was conducted as shown in the Table 3 . below:

Table 3.: Unrestricted Johansen's Co-integration Rank Test (Trace and Max-eigenvalue)

\begin{tabular}{|l|r|r|r|r|}
\hline $\begin{array}{l}\text { Hypothesized } \\
\text { no of CE(s) }\end{array}$ & Eigenvalue & Trace Statistic & $5 \%$ critical value & Prob-ratio \\
None* & 0.49707 & 57.53523 & 54.07904 & 0.0238 \\
At most 1 & 0.407894 & 34.16687 & 35.19275 & 0.0642 \\
At most 2 & 0.26372 & 16.34 .852 & 20.26184 & 0.1587 \\
At most 3 & 0.160287 & 5.939617 & 9.164546 & 0.1954 \\
\hline
\end{tabular}

Trace test indicates 1 co-integrating equation at $5 \%$ level. *denote rejection of the hypothesis at $5 \%$ level of statistical significance.

\begin{tabular}{|l|r|r|r|r|}
\hline $\begin{array}{l}\text { Hypothesized } \\
\text { no of CE(s) }\end{array}$ & Eigenvalue & Max-Eigen & $5 \%$ critical value & Prob-ratio \\
None* & 0.49707 & 25.36836 & 24.58808 & 0.0214 \\
At most 1 & 0.407894 & 17.81835 & 22.29962 & 0.1881 \\
At most 2 & 0.26372 & 10.4089 & 15.8921 & 0.2986 \\
At most 3 & 0.160287 & 5.939617 & 9.164546 & 0.1954 \\
\hline
\end{tabular}

Max-Eigenvalue test indicates 1 co-integrating equation at $5 \%$ level. *denote rejection of the hypothesis at $5 \%$ level of statistical significance.

Source: Authors' Results from E-views 9 for Windows.

According to trace and max-eigenvalue test results, the null hypothesis of no co-integration equation is strongly rejected as the trace and max-eigenvalue statistic were greater than their corresponding critical values at 5 percent significance level. 
Hence, it is concluded that there exists a unique long-run equilibrium relationship between the nominal exchange rate and the selected macroeconomic fundamentals.

The co-integration test as shown in Table 4. is mainly to establish whether this ECM term; derived from the residual of long run regression; is stationary at level or not and to determine how many of such relationships exist. As confirmed from the table, there is significant long run relationship among the variables. Meanwhile, the presence of long run relationship among the variables included in the model does not automatically imply that all the variables in the model have significant effects on the dependent variable. Thus, to determine which variable actually exhibit the observed long run relationship, there is the need to estimate the long run model and then analyse the estimates.

Having established the presence of a single co-integrating vector, the estimation of long-run equilibrium relationship using the Error Correction Model is then conducted. In the first stage, we estimated the co-integration equation for the LEXR by imposing 1 normalizing restriction while in the next stage, we estimated the error correction term arising from the co-integration relation. The result of the estimated co-integrated vector normalized on LEXR is presented in Table 4.

Table 4.: Equation of the co-integrated vector normalized on LEXR

\begin{tabular}{|c|c|c|c|}
\hline $\operatorname{LEXR}(-1)=24.7755-0.9706 * \operatorname{LGDP}(-1)+0.0488 * \operatorname{INFR}(-1)-0.2582 * \operatorname{INTR}(-1)$ & \\
$(4.7129)$ & $(0.17921)$ & $(0.01004)$ & $(0.03614)$ \\
{$[5.25693]$} & {$[-5.41619]$} & {$[4.85823]$} & {$[-7.14422]$} \\
\hline
\end{tabular}

Source: Authors' Results from E-views 9 for Windows.

The long-run relationship between the LEXR and the selected variables showed that LGDP, INFR and INTR are highly statistically significant. In the long run estimation result above, growth of gross domestic product exerted greatest impact on growth rate of exchange rate in Nigeria. That is, a 1.0 percent increase in growth rate of gross domestic product, leads to depreciation of the exchange rate by $9 \cdot 7$ percent elasticity in the long-run; implies that elasticity of growth rate of exchange rate to growth rate gross domestic product is 9.7. While a 1.0 percent increase interest rate leads to 26 percent depreciation in the growth rate of exchange rate. However, 1.0 percent increase in inflation rate leads to a less than 4.8 percent appreciation in growth rate of exchange rate. Thus, result of the error correction model; that is the short-run relationship is presented in Table 5 .

Table 5.: Error Correction Model

\begin{tabular}{|l|r|r|r|}
\hline \multicolumn{1}{|c|}{ CointE1 } & D(LGDP(-1)) & D(INFR(-1)) & \multicolumn{1}{c|}{ D(INTR(-1)) } \\
\hline$-0.044^{321^{*}}$ & -0.025039 & $0.000288^{*}$ & $-0.014401^{*}$ \\
-0.07174 & -0.35269 & -0.00206 & -0.02132 \\
{$[-0.61782]$} & {$[-0.07099]$} & {$[0.14000]$} & {$[-0.67547]$} \\
\hline
\end{tabular}


Standard errors are in () and t-statistics in [ ] *denotes 5 percent level of statistical significance Source: Authors' Results from E-views 9 for Windows.

The estimation discloses that the speed of adjustment coefficient of the LEXR had a negative sign, less than one and highly statistically significant at $5 \%$ level with - 0.044 indicating that any shock in the short-run would be obviated each year by about 4.4 percent and further ascertain the existence of a long-run relationship between the variables. The adjustment process is relatively slow albeit, indicating that any short-run LEXR disequilibrium would be corrected to settle towards its long-run equilibrium value.

Figure 2.: Response of LEXR to Shocks and Variance Decomposition of LEXR
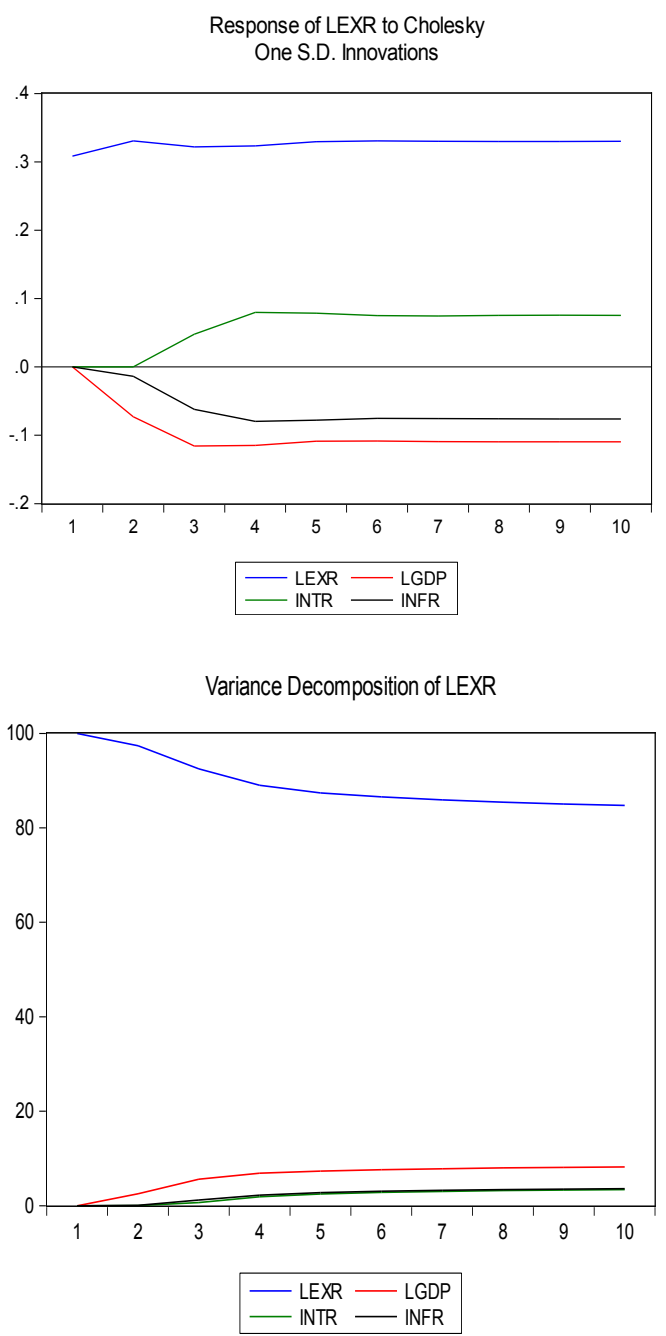

Source: Authors. 
Similarly, the dynamism of exchange rate shocks error correction specification showed that the parameter estimate of the EXR and the three selected variables are statistically significant at 5 percent level of significance.

\section{CONCLUSIONAND POLICY RECOMMENDATION}

This paper examines the dynamism of exchange rate shocks from the view point of three selected macroeconomic fundamentals of domestic prices (inflation), interest rate and nominal gross domestic products (GDP). The existing financial and economic literature such as the purchasing power parity model and the more modern asset market theory to exchange rate were relied upon to conduct the study on the relationship between exchange rate shocks and the three macroeconomic variables.

The estimation result shows that increase in productive output (gross domestic product) would lead to depreciation of the exchange rate in the short run but an insignificant effect in the long run. It hence, implies that dwindling in domestic production has remained one of the major causal factors of the persistent fluctuation in exchange rate in Nigeria. That is, real output has an inverse effect on exchange rate; thus implying that the supply side argument also holds. That is, increasing the supply of goods and services will reduce the pressure on exchange rate. This means that increase in real output can also be used to curtail spiral fluctuation in exchange rate. There are divergent opinions on whether inflation in developing countries like Nigeria, could be explained from monetarist perspective in view of the significant distortions in the supply chain of food and material resources flow in Nigeria and consequently, impacted on the exchange rate. The estimation result shows that persistent rise in price level would lead to appreciation of the exchange rate simply because of over reliance on cheap and more sophisticated foreign goods and materials, at least in the short run but. The domestic interest rate, as reveal by the estimation results, is equally found to significantly impact on the fluctuation of exchange rate in Nigeria. The above results corroborate the findings of Clostermann and Schnatz (2000) that examined the real exchange rate on the euro-dollar relationship and that of T.O. Akinbobola (2012) titled the dynamics of money supply, exchange rate and inflation in Nigeria. Their findings revealed that the international real interest rate differential, relative prices in the goods sector, real oil prices and government spending accounted for significant changes in the real exchange rate.

The overall conclusion is therefore to achieve exchange rate stability in Nigeria, both monetary policy and fiscal policy need to be well coordinated to prevent excessive import of goods and services as well as promoting import-substitution and export of domestic products. Though the selected variables may not be the most important factors in exchange rate determination in Nigeria, the fact that they influence exchange rate in the long run and short run, suggests that sustainable growth of gross domestic product through increased output production and diversifying the 
economy from import based economic activity to export oriented will increase output supply, stability of domestic prices and optimum money supply achieved through disciplined monetary policy are sine qua-non for stable and effective exchange rate in Nigeria.

In view of our findings, the study therefore recommends that a proactive exchange rate policies that promote stability and induce non-tradable activities in the domestic economy is put in place. There is also the need for the economy to be restructured in favour of exports and reduce importation of foreign goods. We in addition, recommend that joint efforts by public and private sectors are put together to stimulate the country's level of production, especially in the area of non-oil outputs to promote export drive and import substitution to enhance inflows of foreign exchange and consequently stabilize the value of naira against other currencies of the world.

To address the influence of pass through of exchange rate into domestic prices, there is need to combine a good mix of macroeconomic policies by the policy makers. An exchange rate policy that shows the prevailing equilibrium conditions is advocated. However, because the pass-through effect of exchange rate is high and the economy is import dependent, a once and for all adjustment of exchange rate could be inimical to the economy by resulting in high pass-through to inflation as evident from year 2016 to the current economic reality in Nigeria. The retention of an overvalued rate is a precursor to loss of external and internal balance.

Most importantly, all the necessary measures to curb inflation especially the consumer price index, must be put in place by the stakeholders. The positive correlation between domestic prices and exchange rate in both the short-run and long run models reveals the destabilizing tendencies of inflation. High volatile domestic prices could lead to distortions in the economy and disequilibrium in the foreign exchange market.

From the aforementioned, an exchange rate policy that would gradually adjust the rate towards its equilibrium position must be encouraged. The objectives would be to adopt an exchange rate that would enable the automatic adjusters in the economy correct misalignments when it occurs. Thus, this work recommends gradual depreciation of exchange rate rather than what is being experienced at present in the Nigerian foreign exchange market. 


\section{REFERENCES:}

Abradu-Otoo, Philip. "Monetary Growth, Exchange Rates and Inflation in Ghana: An Error Correction Analysis." (2003).

Acheampong, Kwasi. The pass-through from exchange rate to domestic prices in Ghana. No. 05/14. Bank of Ghana Working Paper, 2004.

Agosin, Manuel R., and Roberto Machado. "Foreign investment in developing countries: does it crowd in domestic investment?" Oxford Development Studies 33, no. 2 (2005): 149-162

Ahmed, Saeed, Rehmat Ullah Awan, Maqbool H. Sial, and Falak Sher. "An econometric analysis of determinants of exchange rate in Pakistan." International Journal of Business and Social Science 3, no. 6 (2012).

Akinbobola, T. O. "The dynamics of money supply, exchange rate and inflation in Nigeria." Journal of Applied Finance and Banking 2, no. 4, (2012): 117

Al Samara, Mouyad. "The determinants of real exchange rate volatility in the Syrian economy." Centre d'Economie de la sarbonne, universite Paris (2009).

Alfaro, Laura, Areendam Chanda, Sebnem Kalemli-Ozcan, and Selin Sayek. "FDI and economic growth: the role of local financial markets." Journal of international economics 64, no. 1 (2004): 89-112

Arghyrou, Michael G., and Georgios Chortareas. "Current account imbalances and real exchange rates in the euro area." Review of International Economics 16, no. 4, (2008): 747-764

Aschauer, David Alan. "Is public expenditure productive?" Journal of monetary economics 23, no. 2 (1989): $177^{-200}$

Baba N., Sani B. and Ali G. (2012), the monetary model of Exchange Rate Determination: the case of Nigeria. Economic and Financial Review, CBN.

Bacchetta, Philippe, and Eric Wincoop. "Why do consumer prices react less than import prices to exchange rates?." Journal of the european economic association 1, no. 2-3 (2003): 662-670

Bailliu, Jeannine, and Michael R. King. "What Drives Movements in Exchange Rates?." Bank of Canada review 2005, no. Autumn (2005): 27-39

Balasubramanyam, Venkataraman N., Mohammed Salisu, and David Sapsford. "Foreign direct investment and growth in EP and IS countries." The economic journal (1996): 92-105.

Barro, Robert J. "Government spending in a simple model of endogeneous growth." Journal of political economy 98, no. 5, Part 2 (1990): S103-S125

Baxter, Marianne, and Robert G. King. "Measuring business cycles: approximate band-pass filters for economic time series." Review of economics and statistics 81, no. 4 (1999): 575-593

Bengoa, Marta, and Blanca Sanchez-Robles. "Foreign direct investment, economic freedom and growth: new evidence from Latin America." European journal of political economy 19, no. 3 (2003): 529-545

Bhagwati, Jagdish N. "Anatomy of Exchange Control Regimes." In Anatomy and Consequences of Exchange Control Regimes, NBER, (1978): 7-52

Blomström, Magnus. "Foreign investment and productive efficiency: the case of Mexico." The Journal of Industrial Economics (1986): 97-110 
Branson, William H. "Macroeconomic determinants of real exchange rates." (1981).

Burstein, Ariel T., Joao C. Neves, and Sergio Rebelo. "Distribution costs and real exchange rate dynamics during exchange-rate-based stabilizations." Journal of monetary Economics 50, no. 6 (2003): 1189-1214

Burstein, Ariel, Martin Eichenbaum, and Sergio Rebelo. "Large devaluations and the real exchange rate." Journal of political Economy 113 , no. 4. (2005): 742-784

Burstein, Ariel, Martin Eichenbaum, and Sergio Rebelo. Why is inflation so low after large devaluations? No. MT-DP-2003/8. IEHAS Discussion Papers, 2003.

CBN. "Central Bank of Nigeria Statistical Bulletin." (2006).

Clostermann, Jörg, and Bernd Schnatz. "The determinants of the euro-dollar exchange rate-Synthetic fundamentals and a non-existing currency." (2000).

Conway, Paul, Aaron Drew, Ben Hunt, and Alasdair Scott. "Exchange rate effects and inflation targeting in a small open economy: a stochastic analysis using FPS." In BIS Conference Papers, vol. 6, p. 23. 1998.

Dornbusch, Rudiger. "Expectations and exchange rate dynamics." Journal of political Economy 84, no. 6 (1976): $1161-1176$

Due, P. and Sen, P. "Capital flow Volatility and Exchange Rates: The Case of India" Central for Development Economics, Department of Economics, Delhi School of Economics. (Working Paper No. 144) (2006).

Edwards, S. "Exchange Rate Regimes, Capital Inflows and Crisis Prevention", NBER and University of California (Working Paper) (2001).

Feyzioglu, Mr Tarhan. Estimating the equilibrium real exchange rate: an application to Finland. No. 97109. International Monetary Fund, 1997.

Ghosh, Atish R., Anne-Marie Gulde, Jonathan D. Ostry, and Holger C. Wolf. Does the nominal exchange rate regime matter?. No. w5874. National Bureau of Economic Research, 1997.

Gujarati, Damodar N. Basic econometrics. Tata McGraw-Hill Education, 2009.

Harberger, Arnold. "Economic adjustment and the real exchange rate." In Economic adjustment and exchange rates in developing countries, University of Chicago Press, (1986): 369-424.

Husain, Aasim M., Ashoka Mody, and Kenneth S. Rogoff. "Exchange rate regime durability and performance in developing versus advanced economies." Journal of monetary economics 52, no. 1 (2005): $35-64$

Ito, Takatoshi, and Kiyotaka Sato. Exchange rate changes and inflation in post-crisis Asian economies: VAR analysis of the exchange rate pass-through. No. w12395. National Bureau of Economic Research, 2006.

Jhingan M. L. International Economics, 5 th Edition, Vrinda Publications (P) Limited Delhi (2005).

Kamin, Steven B., and Marc Klau. "A multi-country comparison of the linkages between inflation and exchange rate competitiveness." International Journal of Finance \& Economics 8, no. 2 (2003): 167-184.

Knetter, Michael M. International comparisons of pricing-to-market behavior. No. w4.098. National Bureau of Economic Research, 1992.

Krugman P. Obstfeld and Melitz, International Economics: Theory and Policy. Textbook on International Economics (9th Edition) Pearson Education Limited. (2013)

Krugman, Paul R. "Pricing to market when the exchange rate changes." (1986). 
Krugman, Paul R. International economics: Theory and policy, 8/E. Pearson Education India, 2008.

Meese, Richard A., and Kenneth Rogoff. "Empirical exchange rate models of the seventies: Do they fit out of sample?" Journal of international economics 14, no. 1-2 (1983): 3-24

Meese, Richard, and Kenneth Rogoff. "The out-of-sample failure of empirical exchange rate models: sampling error or misspecification?" In Exchange rates and international macroeconomics. University of Chicago Press, 1983.: 67-112

Mike. I. Obadan "lecture materials on International Trade and Finance" (undated).

Milton A.Iyoha and Nosakhare L. Arodoye "An Econometric Analysis of the relationship between Employees' Compensation and selected macroeconomic variables "Journal of West African Institute for Financial and Economic Management (2014).

Mirchandani, Anita. "Analysis of macroeconomic determinants of exchange rate volatility in India." International Journal of Economics and Financial Issues 3, no. 1 (2013): 172

Mishkin, Frederic S. The economics of money, banking, and financial markets. Pearson education, 2007.

Odusola, A. F., and A. E. Akinlo. "Output, inflation, and exchange rate in developing countries: An application to Nigeria." The Developing Economies39, no. 2 (2001): 199-222

Omolara O. Duke, Oladunni A. and Ribadu A. Ahmadu "still on the Equilibrium Real Exchange Rate of the Naira: A Real Examination" Central Bank of Nigeria: A Journal of Economic and Financial Review (Vol. 50, no 3) (202)

Quirk, Peter J. Fixed or Floating Exchange Regimes: Does it Matter for Inflation?. No. 94-134. International Monetary Fund, 1994 .

Rabanal, Pau, and Gerd Schwartz. "Exchange rate changes and consumer price inflation: 20 months after the floating of the real." IMF Country Report: Selected Issues and Statistical Appendix (Section V) (2001): 100.

S Ndungu, Njuguna, and Dick Durevall. "A Dynamic Model of Inflation for Kenya 1974-1996." (1998).

Sadeghi, M., Samsani, H., Sherafat, N. "Inflation-Targeting Policy for an Oil producing country: The Case of Iran". International Research Journal of Finance and Economics. ISSN, $1450-2887$ (2007).

Simon W.L.S. "Is There Life Outside the ERM? An Evaluation of the Effects of Sterling's Devaluation on the UK Economy", International Journal of Finance and Economics, 2, (1997): 199-216

Sims, Christopher A. "Macroeconomics and reality." Econometrica: Journal of the Econometric Society (1980): 1-4.8

Taylor, J., "Low Inflation, Pass-Through and the Pricing Power of Firms", European Economic Review, 1389-14,08 (2000): 44

Toyin S. Ogunleye, Nkenchor N. Igue and Adebola A. Aremu,, 'Transmission of Exchange Rate shock into domestic prices: does it exist for Nigeria." Economic and Financial Review, CBN.

ur Rehman, Mushtaq, and Shafiq ur Rehman. "RELATIONSHIP OF EXCHANGE RATE WITH VARIOUS MACRO ECONOMIC VARIABLES." (2002).

Yuan, Chunming. "The exchange rate and macroeconomic determinants: Time-varying transitional dynamics." The North American Journal of Economics and Finance 22, no. 2 (2011): 197-220

Zubair, Abdulrasheed, Okorie George, and Aliyu Rafindadi Sanusi. "Exchange Rate Pass-Through to Domestic Prices in Nigeria: An Empirical Investigation." (2013). 


\section{APPENDIX}
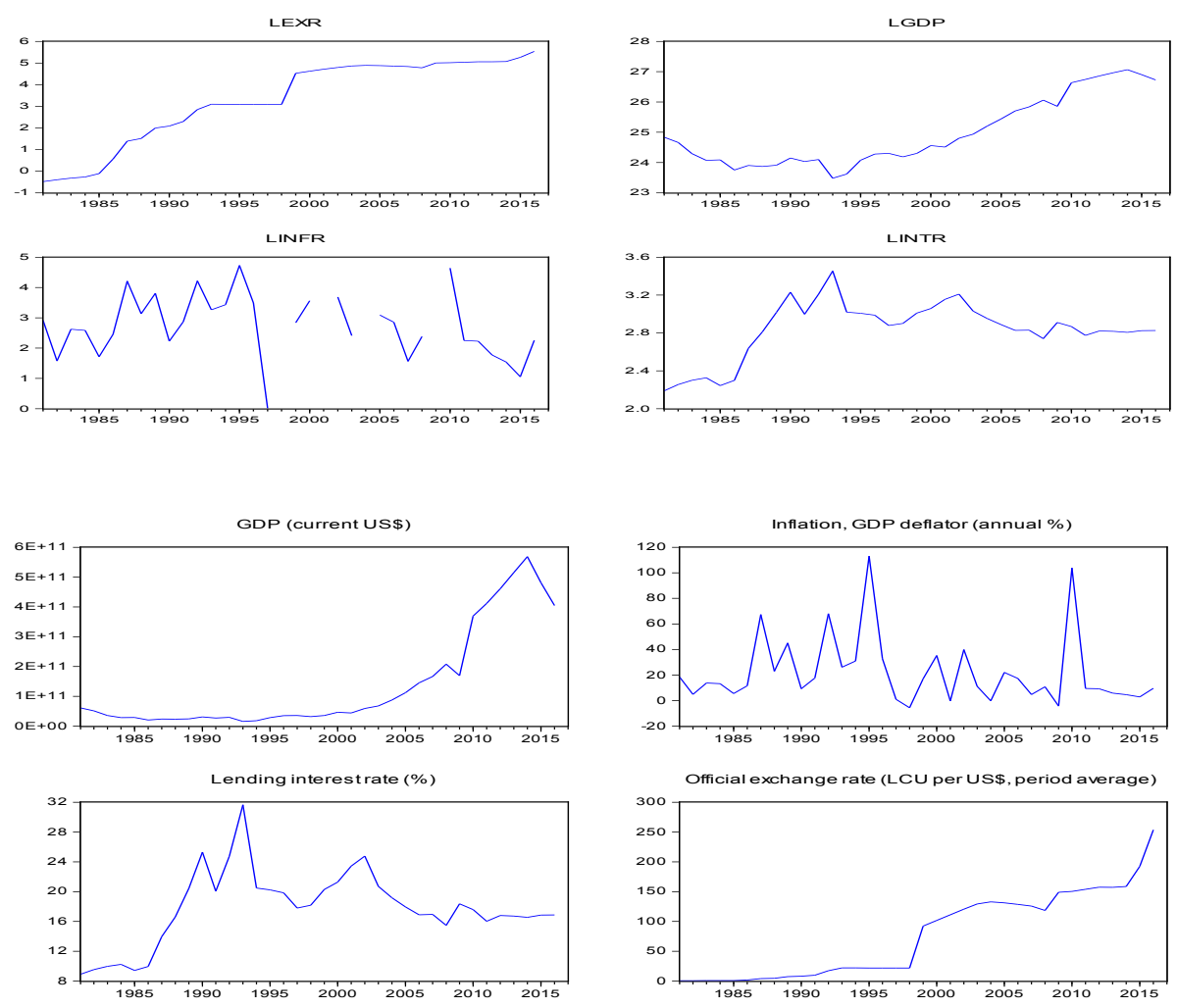

Source: Authors. 

